\title{
Espionage in Bulgarian and Latvian Criminal Law - Comparative Legal Analysis
}

\author{
Petar Koev \\ St. Cyril and St. Methodius University of Veliko Turnovo, Bulgaria \\ Doctoral student at the Department of Criminal Law, \\ Faculty of Law \\ petar_koev@abv.bg
}

\begin{abstract}
The definition of espionage classifies it as an activity that involves gathering information, secret sending of it or its theft, the purpose of which is to subsequently provide the third party with certain sensitive information. In a narrower sense, espionage is understood as a type of crime that affects a country's external security. The article discusses the development and problems of criminal legislation designed to combat espionage activities in Bulgaria and Latvia by analysing the development of historical-legal and comparative-legal criminal laws on espionage. The results of the study suggest that legislation on the protection of the states' secrets has been developed not only according to historical circumstances of both countries, but also in the light of current regional needs and national political priorities.
\end{abstract}

Keywords: espionage, criminal law, state secret, classified information, confidential information, divulgation.

\section{Aim}

The study aims to present current issues in the laws and practices of both countries in the field of protection of state secrets against espionage.

\section{Materials and Methods}

The methods applied for the needs of the study include historical, comparativeand-legal, logical-and-legal methods. 
Petar Koev. Espionage in Bulgarian and Latvian Criminal Law -

Comparative Legal Analysis

\section{Introduction}

As a specific public phenomenon, espionage (spying) is associated with the activity of the state and establishment of the first state entities. Being deversified intelligence directed against the security of a country, spying is undoubtedly one of the oldest crimes against the state. Some authors define espionage as "old as the world".

Historically espionage was initially applied in the field of warfare and opposition between tribes and, at a later stage, between states.

It is well known that even as early as in his poem "Iliad" the ancient Greek poet Homer described that Egyptians had well-developed secret services performing espionage and subversion. Herodotus reported that in $480 \mathrm{BC}$, before his crusade against the Persians, the Greeks sent out three spies to investigate how big the army of Xerxes was $[31,12]$. Fragmentary information on espionage and use of spies is also found in historical sources and references of Ancient Egypt, Ancient Greece, Syria, the Roman Empire, China, Japan. Evidence of spying is also found in the Bible according to which Moses sent his emmisaries spies to explore the lands of Canaan before reaching the Promised Land. Data on the role and importance of intelligence and espionage are found in the works of ancient Chinese thinker Confucius and in the military treatise "The Art of Winning" of Sun Tzu, a military strategist and author of philosophical treatises [22, 5-7].

In the Middle Ages, the Catholic Church and many of the rulers in Europe organised their own (intelligence) spy networks to collect information about their opponents. The first established spy organisation, not only as a reconnaissance network under wartime conditions but also in peacetime was the spy organisation named "Transfiguration Order" created by Peter I - Peter the Great in Russia in 1695.

At a later stage, under the conditions of continual military opposition of the main world forces, in the $19^{\text {th }}$ and early $20^{\text {th }}$ centuries, espionage (spying) gradually became a specific phenomenon in international relations and international law, being not only collection of diverse information about enemies, but also a destructive impact on their internal stability. That imposed the necessity of international legal regulation of espionage, first in the Final Act of the First International Peace Conference (The Brussels International Declaration Concerning the Laws and Customs of War from 1874 [5]), and later in the final convensions and declarations (Final Acts) of the Hague Peace Conferences of 1899 and 1907 on the laws and customs of the terrestrial war where espionage (spying) was clearly distinguished from military reconnaissance in wartime [6, 118-119].

In the text of Art. 24 of the Regulations for the Laws and Customs of Terrestrial War - Appendix to the Fourth Convention on the Laws and Customs of Terrestrial War, it was stated that "the military tricks and use of means necessary to obtain information about the enemy and the locality are considered legitimate [10,71-72] and in the text of Art. 29, it is defined which persons should be considered "spies":

"A spy can only be considered a person who, by acting secretly or on false grounds, collects or attempts to collect data in the war zone of a warrior with the intention to announce 
Petar Koev. Espionage in Bulgarian and Latvian Criminal Law -

Comparative Legal Analysis

them to the opposing party. Therefore, undisguised military personnel who have penetrated the hostile military zone for the purpose of gathering information are not considered spies. Those are also considered to be spies: the military and non-military persons who carry out their task openly, who are charged with transmitting messages intended either for their own army or for the enemy army. Those sent to handle messages and maintain the connection between different parts of the army or territory also belong to this category of persons." [10]

In the $20^{\text {th }}$ century, espionage began to be perceived as a very natural international political activity, as all competing states wishing to internationally gain a prominent position over other countries began to benefit of collecting reconnaissance information. With the development of the modern national state, espionage acquired the utmost importance becoming a major part of the work of governments in most countries.

Today the increasing pace of development of information technology and technical progress over the last decades has greatly expanded the possibilities for foreign intelligence services, organisations and individuals to collect and unhindered transmit extremely valuable political, social, economic, scientific, technical and intelligence information.

The concept of espionage of the United Kingdom's domestic Counterintelligence Service (MI5), one of the most prominent security services in the world, is similar, and, according to it,

"in the past espionage was usually aimed at obtaining political and military reconnaisance information. These goals are still crucial but in today's technology-driven world the intelligence requirements of a number of countries are wider than used to be. Now they include communication technologies, IT, energy, research, defense, aviation, electronics and many other areas ...". [7]

\section{Essence and Definition of the Concept of Espionage}

An important task in this study is to provide the most comprehensive definition of "espionage".

According to well-known definitions of "espionage", the term is used in two ways in a broad sense, as an activity consisting of collecting, secret transmitting or theft aimed to subsequently transmit certain hidden information and, in a narrow sense, the criminal aspect - as a type of crime affecting the external security of a state.

The definitions of espionage given in some references state that it is receiving or transmitting information to the enemy, which could harm the security or interests of the state or could be used by the enemy $[4,508]$. Others associate espionage with the practice of using intelligence spies to acquire information about what another government or company is doing or planning to do [3, 505]. According to Ilyin, "the public danger of espionage lies in the fact that important data that constitute a state secret go out of 
Petar Koev. Espionage in Bulgarian and Latvian Criminal Law -

Comparative Legal Analysis

state control. Espionage is a kind of crime that could create additional preconditions for committing other crimes against the foundations of the constitutional system or state security" [23, 787].

The current definition given by MI5, "espionage" is seen as a

"process of receiving information that is not publicly available using human resources (agents) or technical means (such as hacking in computer systems). Espionage may include specific objectives aimed at influencing decision-makers and creating public opinion in favour of the foreign power interests" [2].

The concept of the US Department of Defense is similar defining "espionage" as

"an act of receiving, providing, transmitting, communicating or receiving information on national defense with intent or reason to consider that information might be used to the detriment of the United States or benefit of any foreign country" [1].

Of all above-mentioned definitions, espionage (spying) can be defined as a particularly significant public phenomenon, which in its essence is the execution of unlawful intelligence by foreign governments or representatives of foreign states expressed in theft or acquisition of a state secret (classified information) or other protected information owned by another country for the purpose of transmitting it to an opposing state or organisation.

The fact that espionage is directly related to the intelligence activity and the concept of "state secret" is also confirmed by the definitions contained in most conceptual and legal glossaries:"Espionage - a crime that consists of collecting or issuing data that present state secret on the purpose to give them to a foreign state or a foreign organisation". [13, 164]

In legal science, spying is also directly related to the concept of "state secret". According to Ivan Nenov, spying should be regarded as a crime closely related to the state secret as the perpetrator issues or attempts to issue or collects the information in order to issue it in the interest of a foreign state or forbidden organisation [20,91]. Yotov describes spying as a specific offense against the republic affecting the state's external security by collecting or issuing state secrets $[38,157]$. Angelov emphasises that one of the most characteristic peculiarities of spying currently is its totality directed towards all aspects of the public life of states, for revealing state secrets of military, political and economic nature as well as for collecting other information, which does not constitute a state secret by law, and is carried out with all possible means [9].

Boris Velchev considers spying as a heavy, classical crime against the external security of a state, whose object includes social relation, ensuring confidentiality of those circumstances, the knowledge of which abroad could jeopardise or affect the Bulgarian national interests. Regarding the object of spying, it is made clear that, as far as the content is special in respect to the crimes under Art. 357 et seq. of the Criminal Code, having the state secret also as subjects, the object of the offense here is connected to violation of the state external security $[37,133-134]$. 
Petar Koev. Espionage in Bulgarian and Latvian Criminal Law -

Comparative Legal Analysis

From what has been mentioned so far, it becomes clear that despite the parallel use of "spying" and "espionage" in modern legal and civic vocabulary, it logically follows that both concepts as forms of intelligence activity are used equally meaning concepts of overlapping significance.

\section{Espionage According to the Bulgarian Criminal Code and the Latvian Criminal Law}

\section{Historical notes}

\subsection{Latvia}

The term "spying" used in the Criminal Code of the Republic of Bulgaria (Art. 104, para. 1 of the CC of Bulgaria. The concept "espionage" was also used in all previous criminal laws and codes in Bulgaria) or "espionage" is a concept that for the past years has been imposed from French "espionnage" and Italian "spione" in the international vocabulary, and is directly related to secret collection (acquisition, theft) of documents and information constituting state secrets on the purpose to transmit them to another country $[8,80]$.

During the first years of the $20^{\text {th }}$ century, the criminal legislation related to espionage activity in Bulgaria and Latvia was developed in one and the same direction using similar concepts and contents of this crime close to each other in their formulation and nature.

Instead of espionage, the Criminal Code applied in Latvia at the beginning of the $20^{\text {th }}$ century initially used the term "spying". The fact that the same concept of "spying" was used in the initial stage of modern development of the criminal law systems of Bulgaria and Latvia is not accidental because the source of the criminal code being in force in Latvia since 1903 is the Law for Punishment of Criminals and Reeducation [36] of 15 August, 1845 (Enforced on 1 May, 1846 and undergone different editions in 1857; $1866 ; 1885)[12,68]$ that served as a basis of developing the draft Criminal Law in Bulgaria written by the Russian Legislative Commission in 1886 and subsequently of the first Criminal Law in Bulgaria adopted in 1896 [26].

In the first decades of the $20^{\text {th }}$ century, Latvia applied the Criminal Code of Tsarist Russia (CC) adopted during the rule of Emperor Nicholas II, on 22 March, 1903 [35]. Regarding the application of Royal CC in Latvia, it is characteristic that not all its provisions came into force due to the rapidly changing social and political realities in Russia at the time of its adoption.

Some of the first texts enforced in 1904 were included in the following chapters: "On the Rebellion against the Supreme Power and Criminal Acts against the Holy Person of the Emperor and Members of the Emperor's House", "On the Treason" and "On Rebellion" [19, 70, 80-82] as one of the basic tasks of this Code was to preserve and promote the monarchical power and security of state.

All texts of the Russian Imperial Criminal Code came into force and were applied only to the territory of Poland, Latvia, Lithuania and Estonia [18, 21] from 1904. 
Petar Koev. Espionage in Bulgarian and Latvian Criminal Law -

Comparative Legal Analysis

Despite the change in the socio-political system in Russia due to the Revolution of October 1917, the provisions of the CC of Tsarist Russia did not lose their relevance and had a significant impact on the content of legal acts in Latvia also during the Soviet period $[34,22]$. The first Soviet Criminal Code based on the principles of socialist criminal law was adopted in 1922. For the needs of the criminal policy of the Union of Soviet Socialist Republics (USSR) established by the treaty of 30 December, 1922 [25, 64], as the "Basic Principles of the Criminal Law of the USSR and the Allied Republics" were adopted in 1924. Shortly thereafter, on 22 November, 1926, the Criminal Code of the RSFSR (in force since January 1927) was adopted. In the period 1927-1935 all allied republics adopted their own criminal codes, a variation of the Criminal code of RSFSR of the RSFSR but with some differences in national and local peculiarities [19, 80-82].

Until 1 April, 1961, under the Decree of the Presidium of the USSR Supreme Council, the RSFSR Criminal Code of 1926 was applied on the territory of the LSSR. By decision of the Presidium of the USSR Supreme Counsil of 11 February, 1957, after the extension of the allied republics' rights on independent adoption of their own criminal codes, on 6 January, 1961 the Latvian Soviet Socialist Republic (LSSR) [30] adopted a new Criminal Code [32].

Chapter One of the new Criminal Code was devoted to crimes against the state as well as crimes against economic and interior security of the state. The crimes against the state are divided in two sections: "Particularly Dangerous Crimes against the State", and "Other Crimes against the State". The provisions of Section 1 of the Code, "Particularly Dangerous Crimes against the State", concerning a wide range of crimes against the state, in the text of Art. 60, there are two types of espionage as crime: espionage committed by a USSR citizen and espionage committed by a foreign citizen or a person without citizenship, as well as privileged provisions under Art. 59.

After the collapse of the USSR, a tendency for a hasty change in the assessment of existing socialist law emerged as all former republics of the Soviet Union adopted new criminal codes taking a course of convergence with the Roman-German legal system not only by their external form, but also by contents [39,34].

With the decree of the Superior Council of the Republic of Latvia dated from 29.08.1991 related to adopting legal acts on the territory of the Republic of Latvia, it was decided to apply the Criminal Code of the LSSR until adopting the new Criminal Code of the republic. According to the changes from 1991, the text of the crime under Art. 60 of the CC of Latvia was divided in two parts as the object of the first one involves only the state and military secrets and the second part contains other information falling out of the main text. Criminal liability is also differentiated as the liability provided for the grave crimes тежкият състав (Eng. heavy composition) under para. 1 is imprisonment for a period from five to 15 years and confiscation of property, and according to the second text liability is from three to ten years with the confiscation of property.

The Criminal Law, which is currently in force in Latvia, was adopted on 17 June, 1998 (in force since 1 April, 1999). With its adoption, the work on a new criminal code 
Petar Koev. Espionage in Bulgarian and Latvian Criminal Law -

Comparative Legal Analysis

under the name Criminal Law having begun at the end of 1990, was completed. While drafting the law, the provisions of earlier Criminal Code of Latvia of 1961, the pre-war Criminal Code of 1933 and the experience in the field of criminal legislation both in the Western European countries (Germany, Sweden, France, Denmark) and in the Russian Federation, Lithuania and Estonia were used [17, 174].

\subsection{Bulgaria}

Concerning espionage crimes, the Bulgarian legislation is exceptionally consistent as the text of crime constantly includes issuing data and information, which is a state secret, to a foreign state as a main substantial feature.

During the first years after Liberation, the restored Principality of Bulgaria still applied the Criminal Law of Ottoman Empire of 1858 [10], which settled the criminal legal regime of the subject of Ottoman Empire. The first Bulgarian Criminal Law was adopted later, in 1896 [26]. During the next several decades, the law underwent numerous amendments aimed to satisfy the dynamics of social relations and the changes of political system. From 1896 to 1936 the texts of espionage were considered in Art. 111, item 2 and item 7 and in Art. 112 of the Criminal Law - in wartime and in periods of peace - in Art. 162 as all required that the data and documents issued or collected with the purpose to issue presented a state secret. In this period, due to lack of legal definition of a state secret, the legal science and judicial practice accepted that the state secret consisted of such facts, data and information that the foreign state or enemy did not have to know. In 1936 with the adoption of Regulation-Law of changing and amendment of the Criminal Law [27], the legal definition of the concept of state secret was written in the text of Art. 112, para. 2 of the Criminal Law. In practice, this definition widened the range of doctrinal understanding and judicial practice of state secret existing until then, and the provided criminal liability for espionage was increased to death or strict imprisonment for not less than ten years. According to this change, a state secret includes facts and data or objects (e.g. letters, maps, drawings, etc. of military, political, economic, etc. nature), which should be unknown for another state in favour of the Bulgarian state and particularly for its security and protection.

With the change of social and political system and turning it into socialist, Law of changing and amendment of the Criminal Law and other laws [28] was adopted on 07.04.1948 as the concept of state secret was widened in Art. 112, para. 2 of the Criminal Law (According to para 14 of the Law for Amendment of the Criminal Law and Other Laws, "state secrets are data on questions enumerated in a list approved by the Council of Ministers and published for general knowledge").

Later, in 1948, the first list of data, information and questions being state secrets, according to Art. 112 of the Criminal Law, were published. The latter were added to the data which were a state secret because of their nature (Publ. SG, No. 261 from 6 November, 1948. The data in this list are classified in two sections: a) data, information and questions of military nature, and b) information of economic nature. It is recognised 
Petar Koev. Espionage in Bulgarian and Latvian Criminal Law -

Comparative Legal Analysis

in section of information of economic nature that data of industry, agriculture, trade and communication present a state secret. The section includes data from the area of industry; trade; agriculture; planning, reporting and statistics; electrification; post, telegraph and telephone offices; transport, nature treasures; building sites and roads; public health; Bulgarian National Bank, etc.).

The provisions of Art. 83, para. 3 of the first socialist Criminal Law in Bulgaria from 1951 (Publ. Izvestiya, No. 13 from 13 February, 1951, enforced from 13 March, 1951 "State secrets are facts, information or objects, such as letters, maps, drawings, etc., of military, political, economic or other nature, the non-recognition of which is necessary for the interests of the People's Republic and especially for its safety. State secrets are also considered as information on issues listed in a list issued by the Council of Ministers and duly promulgated", as mentioned in Izvestiya, No. 91 from 13 September, 1956, SG, No. 58 from 18 July, 1964) contained a more complete definition of state secret as facts and data being a state secret were published in a list, which was hanged and amended many times throughout the years [14].

The codification of the Bulgarian criminal legislation was finished with the adoption of the Criminal Law in 1968 [29], which is still in force currently. The contents of spying crime are included in Chapter I of the Special Part, in the provisions of Art. 104 and Art. 105, respectively. These articles have not been subjected to any changes regarding the elements of crime contents by now. Only the text of Art. 104, item 3 of the Criminal Code was subjected to a substantial change related to the definition of state secret (Amend. SG, No. 95 from 12 December, 1975, amend. SG, No. 99 from 22 December, 1989, amend. SG, No. 10 from 5 February, 1993, amend. SG, No. 50 from 1 June, 1995, amend. SG, No. 153 from 23 December, 1998), the method used to define its content as well.

\section{Contents of spying in Bulgaria and Latvia}

Initially, texts related to the crime of "spying" in Latvia were listed in Chapter Four of the "Treason against the State" of the Criminal Code (Cf. Art. 108, para. 6; Art. 111-113; Art. 118-119) [35; 95-100]; and in the Principality of Bulgaria they were included in Chapter 2 "Betrayal" of the Criminal Law [26] defining it as a crime of treason.

With differentiation of criminal liability introduced in the Criminal Code in Latvia (in force since 1 August, 1921), the text of Art. 108, item 6 clarified that "spying" is a heavy crime of treason guiltily committed by a Russian citizen in the promotion or support of the enemy as this crime is subject to the most severe punishment - death. The same punishment based on the same ground under this article was provided for a Russian citizen involved in preparation of a serious crime directed against a Russian-allied foreign state.

During the same period (form the end of the $19^{\text {th }}$ century to the beginning of the $20^{\text {th }}$ century) the texts of "spying" as a crime in the Principality of Bulgaria were considered in several articles: for spying in wartime under Art. 111, item 2 and item 7, Art. 112 and Art. 113 systematically included in Chapter 2 "Betrayal" of the Criminal Law of 1896 [26],while spying in peacetime was regulated in Art. 162 of the same law. 
Petar Koev. Espionage in Bulgarian and Latvian Criminal Law -

Comparative Legal Analysis

Systematic place of espionage crimes in the Bulgarian Criminal Law of 1896 indicated that they were referred as a separate type of betrayal crime. The texts of all articles provided criminal liability for both intentional and unintentional spying where a specific requirement was introduced for the data issued or collected on the purpose to be issued to a foreign country or the documents handed to contain a state secret. According to Nikov, the entire Art. 111 of the Criminal Law was dedicated to the so-called "military betrayal" and the text itself was introduced so that the betrayal actions provided therein could be completed only in wartime because all items mentioned services performed for the enemy.

Besides in the Criminal Law (CL), spying in Bulgaria was also punished under Art. 225 and Art. 226 of the Military Criminal Code when committed by military personnel in wartime or in a locality declared to be martial [21, 100-101].

From a subjective viewpoint, the Criminal Code of the RSFSR applied in Latvia from 1926 until the adoption of the Criminal Code of Latvian SSR in 1961 made a clear distinction between those involved in espionage or the disclosure of classified information without having access to it and those whom such information was entrusted to in their capacity of officials or received by virtue of their employment status.

Art. 111 of the Criminal Code of Latvia, without distinguishing the subject of crime, provided punishment with hard labour for the guilty publication or disclosure of plans, drawings, documents, copies of them or information directly related to Russia's external security, which must be kept secret from a foreign country, to a government or agent of a foreign state not being in war with Russia. If the plans, drawings, documents, copies or information have been entrusted to the guilty person, or if one had become acquainted with them or received them by virtue of his official position but was forbidden to publish or announce them, they had to be punished with hard labour for a certain period of time. Despite the lack of clarification on the subject of crime in this text, it followed that the legislator should have referred only to a Russian citizen because of the fact that the documents protected from disclosure had been entrusted to a person on duty or by virtue of one's official position.

The text of Art. 112 of the CL of Latvia provided imprisonment for the guilty of taking a plan, picture or description of a Russian fortification or roads, a military ship or equipment intended for the defence of the country. The act according to the previous text was punished much more severely; but if it was performed on the purpose of disclosure to a foreign agent or the government of a foreign state, which Russia was not in war with, the imposed punishment was retention in a penitentiary for not more than three years. The same punishment was provided for the person guilty of taking copies of a plan, picture, description, or document, as well as for receiving both such documents or their copies and data from them collected or presented in a written form if the actions had been performed without duly permission in advance. It was necessary that those documents and data were evidently connected with the external security of Russia and that they had to be kept in secret from other states. 
Petar Koev. Espionage in Bulgarian and Latvian Criminal Law -

Comparative Legal Analysis

The text of Art. 113 provided imprisonment for spying of one who purposefully without the necessary permission hid one's title, citizenship or nationality and, through other tricks, broke into Russian fortification, military vessel, or other equipment intended to defend the country. Art. 118 as punishment provided sending to exile for participation of a Russian subject in a group created to perform treason under Art. 108.

Art. 119 provided the same punishment as that imposed to a Russian subject for participation of a foreigner in preparation of criminal acts according to Art. 108 and Art. 118 during one's stay in Russia or if being captured with guilty performance of the same acts. A special text settled the unlawful activity of a person who had denied their Russian citizen but had not accepted citizenship of another state or had taken citizenship of an enemy country after declaring the war or directly before the peaceful relations were terminated; such a person was punished for the act performed with the punishments provided in Art. 108-110.

The subject of crime "espionage", according to Art. 111 item 7 of the Criminal Law of Principality of Bulgaria, can be every Bulgarian or foreign subject (citizen). To underline the subject of crime, the legislator used the word "who" in the beginning of Art. 111 without minding its location - on Bulgarian or another foreign territory. It is of a certain interest to mention the fact that punishments provided for espionage according to this text were exceptionally grave - life sentence, but during wartime - death. Nikov stated a different vision on the correctness of punishing for espionage in peacetime in Bulgaria. He specified that collection of spying information was not always "approved by international good manners". Nikov wrote that "spying is a right of everybody to collect data of the political, economic and military situation of a country and give a possibility to the government of their native country to take advantage of this information" [21]. Furthermore, punishment for spying is necessarily conducted in Bulgarian territory.

The content of crime in Art. 112 of the Criminal Law of Principality of Bulgaria, unlike the contents of Art. 111 item 2 and item 7 of the CL, provided communicating or transmitting a state secret to the enemy, such a secret that was important for external security or significant interest of the state but not included in Art. 111 [15, 235]. The subject of crime can be every Bulgarian or foreign citizen if the committed act has taken place in wartime "because the law has stated communication of documents or data to the enemy, and our enemy is the one who is at war with us" [21, 105]. The text of Art. 112 item 1 of CL settled the so-called "diplomatic betrayal" providing punishment for such officials who had communicated documents and data related to safety and important interests of the Bulgarian state to the enemy. It was possible that these documents have been entrusted or one might have learned about them due to their official position or on the occasion of a special order assigned to him/her. The further texts of the same article settle how such documents have been acquired or learned about in a criminal way as well as learning of such data in any other way not being provided in the same article knowing that they have to be kept in secret. A person guilty of spying can be punished also by deprivation of rights, according to Art. 118 of the CC. A special hypothesis of 
Petar Koev. Espionage in Bulgarian and Latvian Criminal Law -

Comparative Legal Analysis

criminal liability is provided in the text of Art. 113 of the CC, which defines penalties for spying in peacetime and in wartime but without a perpetrator's intention to assist the enemy or damage the state.

The new Criminal Code of the Latvian Soviet Socialist Republic (LSSR) adopted on 6 January, 1961 settled espionage in Chapter 1 "Crimes against the state", Section 1 "Extremely dangerous crimes against the state". The text of Art. 59 of the CC of the LSSR "Treason homeland" [30] defined espionage and intentional issue of state or military secrets to a foreign state by USSR citizens as main treasonous crimes against the native country. The main content of espionage was settled in the text of Art. 60. According to Art. 60 of the CC of the LSSR "Espionage", espionage was defined as transmitting, theft or collection of data presenting a state or military secret for the purpose of giving them to a foreign state, organisation or their agents. Collecting and issuing information presenting a state secret as well as any other data that could be used against the interests of the USSR [32] also considered espionage referred to in Art. 60 of the CC of the LSSR when the act was completed by a foreign citizen or a person without citizenship. When spying was done by a citizen of the USSR, the act was qualified in the sense of Art. 59 item 1 of the CC of the LSSR $[16,172]$. The second part of the text of Art. 59 of the CC of LSSR provided an incentive norm according to which a USSR citizen was not subjected to criminal liability if although being recruted to implement hostile actions against the USSR by foreign intelligence, had not completed any actions to fulfill a criminal assignment and had voluntarily disclosed their connection with the foreign intelligence to authorities.

After the collapse of the former USSR, with the amendments in the CC of the LSSR [33], the systematic place of espionage was preserved in Chapter 1, Section 1 "Crimes against the republic". The subject of crime referred to in Art. 60 was changed - every person; and the subject of crime was expanded as, besides data presenting a state or military secret, to include other data as well out of the first part of the text. The action was expressed in transmitting, theft or collection with the purpose to transmit data - a state secret or other data to be used against the interests of the Republic of Latvia.

After the independence of Latvia from the USSR was restored, the new Latvian Criminal Law adopted in 1998 began to treat espionage as anti-state crime (Art. 85, para. 2 of the CL, adopted on 17.06.1998, in force since 01.04.1999) [40]. The content of espionage was placed in Chapter 10 "Crimes against the state" including responsibility for a wide range of crimes as unlawful actions threatening Latvian national security and independence, political and economic security of the state. The content of crime referred to in Art. 85, para. 1 of the CL provides imprisonment up to 20 years as punishment for one who personally or through another person, by assignment of foreign intelligence, has unlawfully collected, stolen or transmitted information, which is not a subject of disclosure to another country or a foreign organisation, on the purpose to use this information against the interests of the USSR. Stricter criminal liability (imprisonment from five to twenty years or life sentence with confiscation of property) is provided 
Petar Koev. Espionage in Bulgarian and Latvian Criminal Law -

Comparative Legal Analysis

for espionage referred to in Art. 85, para. 2 if the object of criminal asault is related to unlawful obtaining and transmitting of a state secret (legal definition of the concept of a state secret in Latvia is given in Art. 2, para. 1 of About the State Secret, adopted on 17.10.1996 (Latvijas Vēstnesis, 1996, 19. burtnica, 564, lpp.)), personally or through another person, to a foreign state or foreign organisation [40]. According to the law, the state secret is information of military, political, economic, scientific, engineering, etc. type, which has been included in a list approved by the Cabinet of Ministers (The list of objects presenting a state secret was adopted on 25 June, 1997 with regulations No. 226 of the Cabinet of Ministers (Latvijas Vēstnesis. Dokumenti, 1996, 18. burtnica, 580, lpp.) and the lost or unlawful divulgation which could cause damage to security, economic and political interests of the state.

The law does not provide incentive norms with the criminal perpetrator's denial from spying.

A change of the texts related to espionage with the latest amendments of Art. 85 of the CL of Latvia [40]. The new text of law provides criminal liability for unlawful collection of confidential information with intention to be transmitted or for transmitting the data to another state or a foreign organisation personally or through an intermediator or for unlawful collection and transmitting other data to a foreign intelligence by its assignment, personally or through an intermediator as the liability is similar to that of espionage - imprisonment for no longer than ten years and with probation for a term of up to three years. Paragraph 2 of the text on espionage provides heavier criminal liability for unlawful collection of information or transmitting a state secret to a foreign state or foreign organisation, personally or through an intermediator - imprisonment for a term of three to twenty years and probation for a term of up to three years.

Crime of spying referred to in Art. 85 of the Latvian Criminal Law concerns external security of the Latvian state, as the law referred to in para. 1 defines it as a heavy crime; and referred to in para. 2 - as a particularly heavy crime. The subject of the crime referred to in para. 1 is information that does not have to be or other information. Although the latter is not a state secret, divulgation or transmitting it to a foreign state, organisation or intelligence could threaten the interests of the Latvian state. The executive act is expressed in unlawful collection of or transmitting information to a foreign state or intelligence, personally or through an intermediator. Art. 2 provides heavier criminal liability if the acts referred to in previous paragraph about collection of or transmitting information to a foreign state or organisation concerns information presenting a state secret.

From an objective viewpoint, the objective act referred to in Art. 85 of the CL of Latvia is expressed in theft, collection by assignment of foreign intelligence, or transmitting confidential information or data that contain a state secret through communicating them to addressees using different ways - orally, in a written form, by post, through an mediator, with the help of technical means or through telecommunication channels so the data would come to hands of factual authorities, a foreign state or intelligence.

Every person can be the subject of crime. 
Petar Koev. Espionage in Bulgarian and Latvian Criminal Law -

Comparative Legal Analysis

From a subjective viewpoint, the act is performed with a direct intention as the criminal perpetrator has to be aware that their actions of collection, theft and transmitting information, which is a secret or is not a subject to disclosure, damages the interests of the Latvian state.

Bulgarian criminal legislation in the field of espionage during the so-called socialist period (1944-1989) was rather conservative as since the adoption of the Criminal Code of Bulgaria in 1968 the text of the main content of crime has undergone insignificant changes expressed mainly in mitigation of criminal liability and change of the definition of concept of state secret as the subject of crime is only the state secret and the object of crime is directly connected to the internal security of the Bulgarian state, and the object of crime is directly connected to the internal security of the Bulgarian state.

The main content of crime "espionage" [29] has been unchangeably settled in the text of Art. 104, para. 1 of the CC (Art. 104, para. 1 of the CC: One who issue or collect information on the purpose to issue information presenting a state secret to a foreign state or organisation is punished for espionage with imprisonment of ten to twenty years, life imprisonment or life imprisonment without the right of substitution). From a subjective viewpoint, the act in its two forms, issuance or collection, on a special spying purpose to issue information presenting a state secret to a foreign state or foreign organisation, is intentional and can be performed by any criminally responsible person, a Bulgarian or foreign citizen. The unintentional disclosure of a state secret to representatives of a foreign state or foreign organisation, is not espionage. Yet, a crime referred to in Chapter 12, section I of the CC "Crimes against information presenting a state secret and against foreign classified information" when the criminal perpetrator intentionally divulges, announces a state secret to certain persons without having imagined that the latter are related to performance of spying activity in favour of a foreign state or foreign organisation.

The object of crime is a peculiar category of information, which the law defines the state secret. As written in Art. 104, para. 3 of the CC, the information presenting a state secret is defined by a law. The legal definition of the concept "state secret" is given in Art. 25 of the Law of Classified Information Protection (LCIP). According to it, the "state secret" is information defined in the list in Annex 1, the unregulated access to which could create danger or could damage the interests of the Republic of Bulgaria connected with the national security, defence, international policy or protection of the constitutionally settled order [29].

To more correctly understand the forms of the act of crime "espionage" in Art. 104, para. 1 of the CC of the Republic of Bulgaria, it is necessary to make some specifications related to the concepts collection and issue of information that presents a state secret.

Most authors in Bulgaria have assumed that collection of information presenting a state secret is a kind of preparatory activity by the criminal perpetrator. Ivan Nenov has extensively examined the concept of collection considering that it can be implemented through actions various in their kind but in its essential features it has bilateral purpose to learn the respective data (information) after which to be issued [20, 94]. As a specific activity, collection can be implemented using different methods and means, which 
Petar Koev. Espionage in Bulgarian and Latvian Criminal Law -

Comparative Legal Analysis

depend on the possibilities and the specific situation where a criminal perpetrator acts. Collection can be implemented by direct personal monitoring, contacts and personal conversations with persons having the respective information of a state secret available, by theft or another unlawful activity.

According to Boris Velchev, collection in the sense of Art. 104, para. 1 of the CC is an active behaviour directed to obtaining information (orally or by establishing factual authority on the carrier it is contained in) falling into the list in Annex 1 to Art. 25 of the LCIP (the list of information categories subjected to classification as a state secret (Annex 1 to Art. 25 of LCIP) involves three main categories of information grouped by certain properties and topics - information related to defence of the country; information related to the international policy and interior security of the country and information related to the economic security of the country) with the purpose to be issued to a foreign state or organisation $[37,142]$. Due to the above-mentioned, he has accepted that to merely obtain information without the intention of its future (following) issue to a foreign state or organisation would be only appropriate to the contents of crimes against the state secret.

According to Nenov, the issue is sharing the information, which is a state secret, to another person or its direct transmission, if possible. In this case, the issuing process is not limited to merely announcement of this information, but to announcement "in the interest of a foreign state or a prohibited organisation". According to Nenov, issuing itself could not happen technologically by communicating to a representative of a foreign state or organisation, but by re-communication of this information through a more or less complicated agency network, passing through different units and links. Therefore, he accepted that the law does not require the issuance to a foreign state but in the interest of a foreign state $[20,93]$.

Dikov has examined the issue as performed espionage and from the point of view of the stages of crime as completed espionage, as the placement of a person in the service of another state or foreign organisation to spy and collect spy information are the initial stages of spying, which usually ends with the issuance of such information [11, 167]. The clarification made by Velchev is appropriate regarding conclusions drawn by Nenov on issuance and his addition that if the information is saved on a certain medium, its issuance can be done with delivery of the carrier itself [37, 140].

Moreover, his conclusion that it is not always necessary for these two forms of the act of collecting and issuing the state secret to be connected with each other, but they can exist completely independently, is extremely important.

In this sense, when a person has confessed a state secret to a foreign state or organisation, it must not have always been a necessarily preliminary collected information because it is practically possible to have been collected by one person and transmitted by another one. Another possible assumption is that the person who has issued the state secret to a foreign state or organisation has received (collected) it without performing any activity (one receives or has access to such information by virtue of one's official position). 
Petar Koev. Espionage in Bulgarian and Latvian Criminal Law -

Comparative Legal Analysis

With regard to the concepts used in the Criminal Code - "foreign state or organisation", some clarifications are also. According to the linguistic interpretation of the norm, a "foreign state" should be understood as any other country that is not the Republic of Bulgaria, while a "foreign organisation" should be understood as an organisation being either an international or having political, military, social or another nature, or one pursuing public goals where the Republic of Bulgaria does not participate (is not a member).

The opinion of Velchev on the question of whether espionage can be committed in favour of a private organisation established in another country is of certain interest. According to him, a foreign commercial or even political organisation as well as an individual could not threaten and affect the object of violation referred to in Art. 104 of the Criminal Code in such a way as to impose responsibility for spying. In this connection, he considers that, in existence of data on this type of activity, criminal responsibility for crimes under Chapter XII, Section I of the Criminal Code "Crimes Against State Secret Information and against Foreign Classified Information" can be successfully pursued $[37,142]$.

From a subjective viewpoint, "spying" crime is always intentional. The reasons for spying activity are irrelevant to the content of crime and can have been dictated by various inducements - from pure damage of state interests to pursuit of purely material interests, as with the second form of executive act - collection, the law also requires the pursuit of a special espionage purpose. It is irrelevant for the content of crime whether the information issued could be used by the foreign state or not. It is irrelevant for the complexity of the act whether the information provided could be used by the foreign state or not.

Unlike the collection of information being a state secret and placement into service of a foreign state or organisation, which by its very nature is a preparatory activity, the spying activity ends with issuing information that constitutes a state secret. Thus, with issuing information, the act is completed with the fact of its provision, its perception by a representative of a foreign state or organisation or realisation of factual authority over the medium, which it has been materialised on. Art. 104, para. 2 of the Criminal Code provides an incentive norm concerning active acts of the perpetrator on disclosure of their spying activity to authorities, which is a subject to criminal liability in mitigating circumstances.

The second content of espionage settled in the text of Art. 105 of the Criminal Code is subsidiary regarding the main content under Art. 104 of the Criminal Code and could only be applied in cases where there is no typical spying activity under Art. 104, para. 1 of the Criminal Code. According to the text of Art. 105, para. 1 of the Criminal Code, the subject of crime is any criminal responsible person who has consented to be in the service of a foreign state or foreign organisation to serve as a spy. By its very nature, the executive act is expressed in placement in service of a foreign state or foreign organisation. 
Petar Koev. Espionage in Bulgarian and Latvian Criminal Law -

Comparative Legal Analysis

This placement in service is a kind of preparation for committing the crime of espionage under Art. 104, para. 1 of the Criminal Code, which has been raised as a separate crime by the legislator, the completion of which requires only the person's consent for placement in service to perform a spying activity.

Most researchers on espionage assume that putting oneself in service to a foreign state or organisation is a bilateral process requiring agreement between the participants in it - expression of necessity and consent to work with the person placing oneself in service by the representative of foreign state or organisation and on the other hand, readiness to collect and issue (handle) information representing a state secret declared by the person placing oneself in service. The use of the phrase "to serve as a spy" clearly indicates the intention of the perpetrator to establish a continuous state - to assist a foreign state or organisation. Therefore, from the subjective viewpoint, the crime under Art. 105 can only be performed with a direct intent. An additional condition for the compliance with the content of crime under Art. 105, para. 1 is that the perpetrator's criminal activity does not go beyond the scope of prior consent to spying activity. Any targeted actions to collect or transmit information to a representative of a foreign state or organisation would be qualified according to the main text of Art. 104, para. 1 of the Criminal Code.

The regulation of Art. 105, para. 2 of the Criminal Code provides release of a criminal perpetrator who has agreed to serve in the benefit of a foreign state or organisation if voluntarily disclosed oneself to the authorities. The law does not introduce any additional requirement, except for the perpetrator to reveal the fact that he has agreed to serve as a spy, which in practice does not fully justify the exclusion of criminal liability for the perpetrator.

Regarding lack of other requirements related to the application of incentive norm of Art. 105, para. 2 of the Criminal Code, in addition to the disclosure of the activity carried out by the perpetrator to authorities, it would be logical for the regulation to require additional activity of the exposed perpetrator by providing full information about the foreign intelligence service or organisation that he has served, specific facts about the criminal activity as well as certain representatives of the foreign state or organisation one contacts with. In this sense, a proposal de lege ferenda for amending and supplementing the text of Art. 105, para. 2 of the Criminal Code has been made by Boris Velchev who has introduced an additional condition under Art. 105, para. 1 that, except for the disclosure of the criminal perpetrator to the authorities, one has to announce everything known in connection with the crime committed [37, 152].

The practice of the Supreme Court of the Republic of Bulgaria related to espionage crimes is insufficient and contains only a brief comparative analysis of the main text of crime under Art. 104 as well as comments related to the subsidised nature of regulation of Art.105 of the Criminal Code.

With respect to Art. 104, para. 1 of the Criminal Code, the court considers that in order to carry out the composition of the offense, it is necessary for the perpetrator to have issued or collected, with the purpose of issuing a foreign state or foreign organisation, 
Petar Koev. Espionage in Bulgarian and Latvian Criminal Law -

Comparative Legal Analysis

information constituting state secrets, the two preconditions in the law being given alternatively (sufficient presence of one of the two preconditions) and not cumulative.

With respect to Art. 104, para. 1 of the Criminal Code, the court considers that to carry out the contents of crime, it is necessary for the perpetrator to have issued or collected information constituting state secrets on the purpose of issuing to a foreign state or foreign organisation where the two preconditions in the law are given alternatively (the presence of one of the two preconditions is sufficient) but not cumulative. To apply the provisions of the privileged regulation under Art. 104, para. 2 of the Criminal Code, determining criminal liability in circumstances mitigating criminality, if the perpetrator voluntarily reveals the committed crime to the respective authorities, the court considers that the same liability refers to both prerequisites under Art. 104, para. 1 of the Criminal Code (Cf. Decision No. 108 from 18 October, 1973 of the Supreme Court of Criminal Case No. C-96/1973, $1{ }^{\text {st }}$ Criminal Division). To consider spying under Art. 104 of the Criminal Code, it is sufficient for the perpetrator to have collected information for the purpose to issue it to a foreign state or foreign organisation in the future or to have already issued this information to them. No other result - damage - is required to have occurred (Cf. Decision No. 33 from 29 April, 1978 of the Supreme Court of Criminal Case No. 23/1978, $1^{\text {st }}$ Criminal Division).

For assistance in committing a crime referred to in Art. 104 of the Criminal Code, the Supreme Court has expressed opinion that the fact of spying information is transmitted to a foreign citizen who collects such information does not make the person who transmit them an assistant. He remains the perpetrator of the crime referred to in Art. 104 of the Criminal Code.

For the content of Art. 105 of the Criminal Code it is necessary for the perpetrator to be placed in the service of a foreign state or foreign organisation in order to serve as a spy and not to take action for the collection and issuance of the spyware in the meaning of Art. 104 of the Criminal Code. However, if one has developed a spying activity, the perpetrator will be for criminal liability referred to in Art. 104, para. 1 of the Criminal Code (Cf. Decision No. 31 from 4 A pril, 1978 of the Supreme Court of Criminal Case No. 1/1978, $1^{\text {st }}$ Criminal Division).

Contrary to the prevailing opinion of espionage researchers on the fact of accepting to do a favour to a criminal, the judicial practice related to Art. 105, para. 1 of the Criminal Code accepts that for the crime commission it is not necessary to serve as a spy of a foreign state or a foreign organisation to be accepted by their authorities. According to the practice of the court, since such a person has explicitly stated being a spy serving a foreign state, even if the foreign state or organisation has not explicitly accepted that, this person can always be sought to fulfill their promise. No other features are required except for the perpetrator to have given his/her consent to serve as a spy. If one has begun to collect information or data presenting a state secret or to collect and transmit such information, the perpetrator will have committed a crime "espionage", which is the sense of regulation of Art. 105, para. 1 of CC. Besides that, to implement the content of crime, 
Petar Koev. Espionage in Bulgarian and Latvian Criminal Law -

Comparative Legal Analysis

the representative of the foreign state or organisation, which the perpetrator has agreed to serve for as a spy, it is not necessary for this representative to be part of the staff of the foreign intelligence (Cf. Decision No. 42 from 11 April, 1971 of the Supreme Court of Criminal Case No. 49/1971, $1^{\text {st }}$ Criminal Division).

\section{Discussions}

Comparing legal analysis of espionage norms both in Bulgarian and Latvian legislation and considering the current tendencies, the total range and aims of spying activity as well as the current state of legislation in the NATO and EU member states allows for the conclusion that regulations referred to espionage in the Bulgarian Criminal Code and the Latvian Criminal Law provide sufficiently complete and effective protection of social relations regarding keeping the state secret while considering national specificities of legal issues.

In addition to the above mentioned, it should be considered that more attention has to be paid to a problem which has not been sufficiently discussed in the criminal law science, yet has increased its significance - namely, performing espionage and other activities directed to state security through using agents of influence.

Additionally, besides doing mere espionage activity, foreign states aim at using other means to acquire both information and positions in the state by being an object of interest with the purpose to directly influence decision-making and the entire state policy.

As it is known, under current conditions of total intelligence, the main priority in the work of foreign special bodies is, besides receiving information through using technical methods, to acquire agent information and influence through introducing agents (the agent is a person, who has agreed to perform certain functions and tasks on someone's behalf or in someone's favour from the viewpoint of special bodies, those are people who intentionally work to benefit them regardless of their positions - no matter whether their activity is directly connected with them) on different key positions in the state, which is the object of intelligence interest.

The use of so-called agents of influence is not a novelty in spying and inter-state relations. It has been known since antiquity through conclusion of the so-called dynastic marriages. Nowadays, and especially in recent decades, the use of agents of influence is an extremely common practice by foreign intelligence agencies and other organisations. In order to effectively achieve their goals, these agencies and organisations carry out whole sets of activities to acquire and prospectively implement agents for intelligence who would have access not only to important government documents and decision-makers, but also to the very process of discussing and adopting these decisions.

The positions that these individuals have or may acquire as well as the opportunities created for personal contacts with officials occupying key positions in the state and the executive authorities and access to information of interest to a foreign state or organisation give them opportunity to receive information of extremely high degree of 
reliability and significance. Through such positions occupied, they have an opportunity to specify important details for the foreign state or organisation with the planned actions on the state related to a state of interest as well as with the implementation of subsequent control over their completion.

In such intelligence positions objectively created, the agent of influence may have direct or indirect access to original secret documents containing state secrets, as well as to persons directly related to the documents - being their authors, and by engaging them in a conversation to provoke actions or monitor reactions, to specify individual details of interest to a foreign state, intelligence service or organisation and directly affect decision-making of the state. In a certain number of cases, foreign intelligence agencies and organisations, through the actions of agents of influence, directly aim at destabilising the state or even overthrowing the government.

Undoubtedly, realisation of this type of action directly affects external security of a state as these could directly influence internal or international decision-making of the state, as well as have an influence on defining its overall policy. In their nature, such actions should be categorised as a form of assistance to a foreign state against the Republic of Bulgaria as related to Art. 100, para. 2 of the Criminal Code. As far as they have direct purpose to affect certain decisions or the overall state policy in direction desired by the foreign state or organisation, they could also be defined as a form of hostile action.

In this sense, the executive act of crime as referred to in Art. 104 and 105 of the Criminal Code of the Republic of Bulgaria may include acts not only of collection and issuance of information, which is a state secret. Possibility of adopting texts in the Criminal Code providing criminal liability for anti-state activity performed by agents for influence should also discussed. In practice, through their activities, this category of persons creates real preconditions for damaging national security and directly affect national interests.

\section{Conclusions}

Finally, it could be concluded that historical-legal and comparative-legal analysis of criminal laws for espionage in Bulgaria and Latvia has shown that the legislation concerning the protection of state secrets has been developed in compliance with the historical backgrounds of both countries. Similarities in the Criminal Code of Bulgaria and the Criminal Law of LSSR during the so-called socialist period were due to the ideological concept of "state secret" imposed by the political system in the USSR-satellite countries.

Analysis of legislative regulations related to espionage has also defined some common features of amendments made in the legislative acts after the democratic changes in Bulgaria and the development of Latvia after the country became independent from the Soviet Union. 
Petar Koev. Espionage in Bulgarian and Latvian Criminal Law -

Comparative Legal Analysis

However, regardeless being NATO and EU member states, they have the same political values, the legislation on spying in each country has preserved part of its specificity based on national traditions and aims.

The study in this paper has also proved that the regulations of spying have been developing to meet current regional needs and state political priorities.

\section{Spiegošana Bulgārijas un Latvijas \\ krimināltiesībās - salīdzinoša juridiskā analīze}

\section{Kopsavilkums}

Spiegošanas definīcija klasificē spiegošanu kā darbību, kas ietver informācijas vākšanu, slepenu nosūtǐšanu vai tās zādzību, kuras mērḳis ir vēlāk nosūtīt noteiktu slepenu informāciju. Šaurākā nozīmē spiegošana tiek izprasta kā nozieguma veids, kas ietekmē valsts ārējo drošỉbu. Rakstā aplūkota krimināltiesību aktu, kas izstrādāti, lai cīnītos pret spiegošanas darbībām, attīstība un problēmas Bulgārijā un Latvijā, analizējot vēsturiski juridisko un salīdzinoši juridisko krimināllikumu attīstību spiegošanas jautājumā. Pētījuma rezultāti ḷauj secināt, ka tiesību akti par valsts noslēpuma aizsardzību ir izstrādāti ne vien atbilstoši abu valstu vēsturiskajiem apstākḷiem, bet arī ievērojot pašreizējās reǵionālās vajadzības un valsts politiskās prioritātes.

Atslēgvārdi: spiegošana, krimināllikums, valsts noslēpums, klasificēta informācija, konfidenciāla informācija, izpaušana.

\section{References}

1. Dictionary of Military and Associated Terms, Department of Defense, amend. through 15 February 2016.

2. Espionage, available from https://www.mi5.gov.uk/espionage [reviewed 19.06.2018].

3. Garner, B. A. Black's Law Dictionary. 7th ed. West Group, 1999, 505.

4. Martin, E. A., Law, J. Oxford Dictionary of Law. 6th ed. 2006.

5. Project of an International Declaration concerning the Laws and Customs of War. Brussels, 27 August 1874, Art. 19-22, available from https://ihl-databases.icrc.org/ihl/INTRO/135 [reviewed 19.06.2018].

6. Scott, J. B. The Hague Conventions and Declarations of 1899 and 1907. New York: Oxford University Press, 1915, 118-119.

7. Targets of espionage, available from https://www.mi5.gov.uk/targets-of-espionage [reviewed 19.06.2018].

8. Anashkin, G. Z. Otvetstvennosty za izmenu rodine i shpionazh. Moskva: Yuridicheska literatura, 1964. (Анашкин, Г. З. Ответственость за измену родине и шпионаж. Москва: Юридическа митература, 1964.) 
Petar Koev. Espionage in Bulgarian and Latvian Criminal Law -

Comparative Legal Analysis

9. Angelov, M. Shpionstvoto v Narodna Republika Balgariya (kriminologichesko izsledvane). Sofia: ITS pri Glavno politichesko upravlenie na narodnata armiya, 1974. (Ангелов, М. Шиионството в Народна Република България (криминологическо изследване). София: ИЦ при Гкавно политическо управление на народната армия.1974).

10. Arnaudov, Hr. Palno sabranie na darzhavnite zakoni, ustavi, nastavleniya $i$ visoki zapovedi na Osmanskata imperiya, t. 4. Prevedeno ot turski i izdadeno ot Hristo Arnaudov. Sofia: Knigopechatnitsa na Ya. S. Kovachev, 1886. (Арнаудов, Хр. Пълно събрание на държавните закони, устави, наставления и високи заповеди на Османската империя, т. 4. Преведено от турски и издадено от Христо Арнаудов. Книгопечатница на Я. С. Ковачев. София, 1886.)

11. Dikov, A. Predatelski prestapleniya. Sofia: VSSH “Georgi Dimitrov“, 1982. (Аиков, А. Предателски престъпления. София: ВСШ “Георги Аимитров",1982.)

12. Epifanova, Y. V. Ulozheniye o nakazaniyakh ugolovnykh i ispravitelnykh 1845 goda: Prichiny razrabotki i prinyatiya. Ulozheniye o nakazaniyakh ugolovnykh $i$ ispravitelnykh 1845 goda: Kontseptualnyye osnovy i istoricheskoye znacheniye" (k 170-letiyu so dnya prinyatiya): Materialy mezhdunarodnoy nauchno-prakticheskoy konferentsii, gr. Gelendzhik, 2-3 oktomvri 2015 g. Kr., 2016. (Епифанова, Е. В. Уложение о наказаниях уголовных и исправительных 1845 года: Причины разработки и принятия. Уложение о наказаниях уголовных и исправительных 1845 года: Кониептуальные основы и историческое значение (к 170-летию со дня принятия): Материалы межАународной научно-практической конференции, гр. ГеменАжик, 2-3 октомври 2015 г. Кр., 2016.)

13. Georgiev, G., Velinov, L. Yuridicheski rechnik. Sofia: Universitetsko izdatelstvo "Sv. Kliment Ohridski”, 2007. (Георгиев, Г., Велинов, А. Юридически речник. София: Университетско издателство “Св. КАимент Охридски”, 2007.)

14. Izvestiya, No. 22 from 16 march 1951; amend. Izvestiya, No. 67 from 21 August 1956.

15. Koev, P. Darzhavnata tayna v Balgariya $i$ nakazatelnopravnite garantsii za neynata zashtita, De Jure, br. 2, YUF na VTU “Sv. Kiril i Metodiy”, VT: 2015 (Коев, П. Аържавната тайна в България и наказателноправните гаранции за нейната защита, De Jure, бр. 2, ЮФ на ВТУ “Св. Кирим и Методий”. ВТ: 2015).

16. Kommentariy ugolovnogo kodeksa Latviyskoy SSR. Riga: Liyesma, 1967. (Комментарий уголовного кодекса Аатвийской ССР. Рига: Аиесма, 1967.)

17. Krastinsh, U. Ya. Novy Ugolovnyy zakon Latvii, v Novoye ugolovnoye zakonodatelstvo stran SNG $i$ Baltii. Moskva: “LeksEst”, 2002. (Крастиньш, У. Я. Новый Уголовный закон Аатвии, в Новое уголовное законодательство стран СНГ и Балтии. Москва: АексЭст, 2002.).

18. Kuznetsova, N. F., Tyazhkova, I. M. Kurs ugolovnogo prava. Obshchaya chast. Tom 1: Ucheniye o prestuplenii. Moskva: Zertsalo, 2002. (Кузнецова, Н. Ф., Тяжкова, И. М. Курс уголовного права. Общая часть. Том 1: Учение о преступцении. Москва: Зерцало, 2002).

19. Naumov, A. V. Rossiyskoye ugolovnoye pravo. Obshchaya chast. Kurs lektsii. Moskva: 1996 (Наумов, А. В. Российское уголовное право. Общая часть. Курс лекций. Москва:1996.).

20. Nenov, Iv. Nakazatelno pravo na Narodna republika Balgariya. Osobena chast, Tom 1. Sofia: DI “Nauka i izkustvo", 1956. (Ненов, Ив. Наказателно право на Народна република България. Особена част, Том 1. София: АИ “Наука и изкуство”, 1956.)

21. Nikov, N. Rakovodstvo po osobenata chast na Balgarskiya nakazatelen zakon. Tom 1. Sofia: Narodna pechatnitsa "Vitosha", 1922. (Ников, Н. Ръководство по особената част на Българския наказателен закон. Том 1. София: Народна печатница “Витоша”, 1922.) 
Petar Koev. Espionage in Bulgarian and Latvian Criminal Law -

Comparative Legal Analysis

22. Polmar, N., Alan, T. B. Entsiklopediya na shpionazha. Sofia: Trud, 2001. (Поммър, Н., А^ън, Т. Б. Енциклопедия на шиионажа. София: Труа, 2001.)

23. Rosiyskaya kriminologicheskaya yentsiklopediya. Prestupnost' i borba s ney v ponyatiyakh $i$ kommentariyakh. Moskva: Norma-Infra-M, 2000. (Российская криминологическая енциклопедия. Преступность и борба с ней в понятиях и комментариях. Москва: Норма-Инфра-М, 2000.)

24. Sbornik na mezhdunarodni aktove i dogovori. Pod red. na prof. Kutikov. Sofia: Obsht fond za podpomagane studentite ot visshite uchebni zavedeniya v Balgariya, 1948. (Сборник на международни актове и договори. ПоА реА. на проф. Кутиков. София: Общ фонА за поАпомагане студентите от висшите учебни заведения в Бъцгария, 1948.)

25. Sbornik zakonov SSSR 1938-1967 g. Tom 1. Moskva, 1968. (Сборник законов СССР 1938-1967 2. Том 1. Москва, 1968.)

26. State Gazette (SG), No. 40 from 21 February 1896, adopted on 15 January 1896 by the 8th Ordinary National Assembly (Parliament of Bulgaria), approved by Decree No. 43 from 02.02.1896, multiply amend., cancelled by point 1 of the Transitional Regulations of Criminal Law, Publ. Izvestiya, No 13 from 13 February 1951, enforced from 13 March 1951.

27. State Gazette (SG), No. 42 from 24 February 1936.

28. State Gazette (SG), No. 80 from 07 April 1948.

29. State Gazette (SG), No. 26 from 02 April 1968, Suppl. SG No. 50 from 01 June 1995, amend. SG No. 153 from 23 December 1998, amend. SG No. 26 from 30 March 2004.

30. Svod zakonov Latviyskoy SSR. Vol. 9, 2-1. (Свод законов Аатвийской ССР. Том 9, 2-1.)

31. Stoyanov, Zh. Istoriya na razuznavaneto. Sofia: Albatros, 2002. (Стоянов, Ж. История на разузнаването. София: А^батрос, 2002.)

32. Ugolovnyy kodeks Latviyskoy SSR. Ministerstvo yustitsii Latviyskoy SSR. Riga: Avots, 1983. (Уголовный кодекс \атвийской ССР. Министерство юстиции Аатвийской ССР. Рига: Авотос, 1983.)

33. Ugolovnyy kodeks Latvii. Riga: Alkor, 1993. (Уголовный кодекс Аатвии. Рига: А^кор, 1993.).

34. Ugolovnoye pravo Rossii. Prakticheskiy kurs. Pod obshch. red. A. I. Bastrykina; pod nauch. red. A. V. Naumova. 3-ye izd., pererab. i dop. Moskva: Volters Kluver, 2007. (Уголовное право России. Практический курс. Под общ. реА. А. И. Бастрыкина; под науч. реА. А. В. Наумова. 3-е изА., перераб. и Аоп. Москва: Волтерс Ккувер, 2007.)

35. Ugolovnoye ulozheniye (deystvuyushcheye v Latvii so vsemi izmeneniyami i dopolneniyami, izdanymi do 01 avgusta 1921 g.), Dvinsk: Gorodskaya Tipo-litografiya, 1921. (Уголовное уложение (Аействующее в Аатвии со всеми изменениями и дополнениями, издаными до 01 августа 1921 г.). Авинскъ: Городская Типо-литография, 1921).

36. Ulozheniye o nakazaniyakh ugolovnykh i ispravitel'nykh. SPb., 1873. (Уложение о наказаниях уголовных и исправительных. СПб., 1873.)

37. Velchev, B. Prestapleniya protiv republikata. Sofia: Siela, 2014. (Велчев, Б. Престъпления против републиката. София: Сиела, 2014.)

38. Yotov, B. Prestapleniya protiv republikata. Sofia: Nova zvezda, 2000. (Йотов, Б. Престъпления против републиката. София: Нова звезАа, 2000.)

39. Zubkova, V. I. Ugolovnoye zakonodatelstvo yevropeyskikh stran: Sravnitelno-pravovoye issledovaniye. Moskva: Yurlitinform, 2013. (Зубкова, В. И. Уголовное законодательство европейских стран: Сравнительно-правовое исследование. Москва: Юрлитинформ, 2013.)

40. Krimināllikums. Adopted on 17.06.1998, in force since 01.04.1999, available from https://www. likumi.lv [reviewed 19.06.2018]. 